\title{
Enhancing Students' Vocabulary Mastery Using Spot It! Card Game In Distance Learning
}

\author{
Suci Ayu Kurniah P. ${ }^{1}$, Rusliana ${ }^{2}$,Erna Fitriani Pratiwi ${ }^{3}$ \\ *mrs.suciayu@gmail.com1 \\ 1,2,3Faculty of Nursing, Universitas Indonesia Timur, Makassar,Indonesia
}

Received: 25 October 2020 Accepted: 26 November 2020

DOI: $10.24256 /$ ideas.v8i2.1617

\begin{abstract}
This study aimed at finding the effectiveness of Spot it! Card Game in enhancing students' English vocabulary mastery in distance learning. The research used a quasi-experimental research design. The participants were the secondyear students of SMA Pesantren Modern Datuk Sulaeman Palopo Bagian Putri which were divided into experimental group and control group consisted of 20 students each group. The result indicates that the students ofexperimental grouphave significant improvement of mean score which is5,42 on Pre-testclassified as Poor to 8,89 on Post-test classified as Very Good after given treatment using Spot It! Card Game. Meanwhile, students of control group shows slight improvementwhich is 6,36 on pre-testclassified as Fair to 7,91 on post-testclassified as Good after given treatment using conventional method. It means enhancing students' vocabulary mastery using Spot It! Card Game is more effective than using conventional method in distance learning.
\end{abstract}

Keywords: card game, students, teaching, vocabulary

\section{Introduction}

Vocabulary is the fundamental aspect in learning English. It is even more important than grammar. By mastering vocabulary, people can easily accept and improve the other language skill such as listening, reading, speaking and writing so that, teacher is required to provide strong vocabulary teaching to their students because the students' vocabulary mastery needs to be enhanced.

There have been many studies conducted to improve students' English vocabulary with a variety of interesting strategies and learning media such as Taka (2019) who investigated the effectiveness of pairs teaching in teaching vocabulary at SMA Kristen Mercusuar. Ilinawati (2019)found out song is helpful to improve students' vocabulary mastery for first semester students of English language study program, STKIP PersadaKhatulistiwaSintang, Academic year 2018/2019. Inal(2014) investigated the effects of stories as contexts on vocabulary recognition and 
retention and found that students which were taught vocabulary through stories scored significantly higher than the students which were taught through traditional techniques.

Another successful strategy in teaching vocabulary in the classroom mentioned by Huyen and Nga (2003) was applying games and it was supported by Derakhshan (2015) stated that students can use the language more communicatively by using vocabulary games. However, due to the Covid-19 pandemic situation, students have to study at home and teachers are required to teach online in accordance with Circular Letter Number 15 of 2020 concerning Guidelines for Organizing Learning from Home in an Emergency the Spread of Corona Virus Disease (COVID-19) from Ministry of Education and Culture of Indonesia. Therefore, teachers must provide learning materials that can be used effectively online or in distance learning.

The common tools used for distance learning is Zoom. Guzacheva (2020) who investigated the effectiveness of Zoom for distance learning in teaching English to medical students stated that Zoom grants English teachers different ways of expressing the material of their lessons. The screen sharing of Zoom will provide English teachers with a great opportunity to improve the intercultural skills of medical students by sharing engaging resources such as videos, articles and presentations. English teachers should enable medical learners to use constructive questioning during lessons and after watching them to assess and evaluate their learning. Students may also be asked by educators to focus on their lessons by recording and sharing it.

In terms of vocabulary research, many studies had investigated the effectiveness of cards and games in improving students' vocabulary mastery. In the previous study, Kurniah (2018) investigated the effectiveness of Find A Match Game Card another name of Spot It! Card Game in increasing students' vocabulary mastery of second year students of SMA Negeri 21 Makassar. The result showed the students' achievement on pre-test increased significantly on post-test after given treatment using Find A Match Card Game. Another study such Komachali (2012) found that the contribution of vocabulary flash card in teaching vocabulary to students led to a higher level of vocabulary improvement. Razali (2017) also found "GOT IT!" card game could be useful of classroom teaching where it assisted in retaining the words apparently learned. As seen in the results of the study, this card game helped vocabulary retention capacity better compared to just typical teacher talk in class. Furthermore, the treatment was appreciated by the students because learning was carried out in a fun and unintended way. In particular, the ability to maintain vocabulary is necessary for student to be able to employ them for later use in other English skill such as reading, speaking and writing.

Even though many studies had been conducted in improving students' vocabulary mastery through cards and games, however, investigating the effectiveness of card game in improving students' vocabulary mastery in distance 
learning is such be a consideration. Therefore, the researcher proposes a research question: "How effective is Spot It! Card game in enhancing students' vocabulary mastery in distance learning?". The objective of this study is to find out the effectiveness of Spot It! Card Game in enhancing student's vocabulary mastery in distance learning.

Theoretically, the research outcome is expected to lead to the advancement of theory for teachers and learners on one way to improve the vocabulary of students in teaching English as a foreign language. Furthermore, the findings may be a motivating factor to promote the implementation of more innovative and interesting learning methods in the English language classroom or in distance learning class. This study can also become an indicator for researchers who are interested in researching the use of card games in more detail.

\section{Method}

The type of this study is a quasi-experimental with two groups. One group as experimental group and another as control group. This study was conducted in SMA Pesantren Modern Datuk Sulaeman Palopo on August to September 2020 through distance learning. The population of this study was all of the students of SMA Pesantren Modern Datuk Sulaeman Palopo. The sample of this study was the second year students which were divided into Experimental Group and Control Group consisted of 20 students each group taken using a quota sampling technique.

Data were collected using vocabulary test, quiz and questionnaire. The instruments of the research were:

1. Multiple choice test

The researcher used a multiple-choice vocabulary test. The type of the test was bilingual vocabulary test on pre-test and post-test to identify the vocabulary mastery of the students of SMA Pesantren Modern Datuk Sulaeman Palopo. The researcher provided 50 items consisted a statement with underlined word and 4 choices of answer. The students would choose the correct answer that suit to the translation of the underlined word.

\section{Spot It! Card Game}

Spot it! Card game contains 55 cards, with 8 symbols per card from the 50 available. Each card is designed with common images or words for early learners, including sight words. There is only one matching symbol in common between each card, it is up to player to find out which one. There are numerous kinds of spot it! Card game such as Spot it! Sport, spot it! Animal and more. The cards were then modified in the form of a presentation so that it could be used in distance learning through Zoom Meeting.

3. Quiz

The researcher used quizzes as review of students' vocabulary knowledge after taught using Spot It! Card Game. 


\section{Questionnaire}

The researcher used questionnaire to know students' impression of the implementation of Spot It! Card Game in learning vocabulary during distance learning.

In this study, experimental group and control group conducted pre-test and post-test. The pre-test was given to both groups at the beginning of the research. The experimental group was given treatment using Spot It! Card Game for several meetings. They played the card game in group of 4 . Each group consisted of 5 students. They competed to find the same image of each card displayed in the slides and mentioned the name of the image in English. The students were also given quizzes to review their knowledge of the vocabulary they had learned from Spot It! card game. The control group was also given treatment using conventional method. The researcher gave the post-test to both experimental group and control group after conducted the treatment. All treatment and tests were given online through presentation in Zoom Meeting during distance learning. At the end of the research, the researcher gave questionnaire made using google form to students to know their impression in learning vocabulary while playing Spot It! Card game.

Data were analyzed and tabulated using IBM SPSS Statistics 25 software. The results were reported based on the mean score of both pre-test and post-test. After analyzing the data, the students' score was classified into 7 categories as follow:
a. $\quad 9.6$ to 10 is classified as excellent
b. $\quad 8.6$ to 9.5 is classified as very good
c. $\quad 7.6$ to 8.5 is classified as good
d. $\quad 6.6$ to 7.5 is classified as fairly good
e. $\quad 5.6$ to 6.5 is classified as fair
f. $\quad 3.6$ to 5.5 is classified as poor
g. $\quad 0.0$ to 3.5 is classified as very poor

\section{Results}

\section{Students' Minimum and Maximum Score}

The result of this study before and after giving treatment using Spot It! Card Game to students in learning vocabulary is described as the table below:

Table 1. The Students' Minimum and Maximum Score on Pre-test and Post-test

\begin{tabular}{lcccc}
\hline Statistic & $\begin{array}{c}\text { Pre-test } \\
\text { Experimental } \\
\text { Group }\end{array}$ & $\begin{array}{c}\text { Pre-test } \\
\text { Control } \\
\text { Group }\end{array}$ & $\begin{array}{c}\text { Post-test } \\
\text { Experimental } \\
\text { Group }\end{array}$ & $\begin{array}{c}\text { Post-test } \\
\text { Control } \\
\text { Group }\end{array}$ \\
\hline Minimum & 3,0 & 2,4 & 4,6 & 3,8 \\
Maximum & 9,0 & 9,2 & 10,0 & 9,8 \\
\hline
\end{tabular}

Table 1 shows that the minimum score of students on Experimental Group was increased from pre-test 3,0 to 4,6 on post-test after given treatment using Spot It! 
Card game. While the minimun score of students on Control Group was also increased from 2,4 to 3,8. The maximum score of students on Experimental Group was increased from 9,0 on Pre-test to 10,0 on Post-test after given treatment using Spot It! Card Game. The maximum score of students of Control Group was also increased from 9,2 on Pre-test to 9,8 on Post-test after given treatment using conventional method. The increasing score is not as significant as the score of students on Experimental Group.

Students' Score Classification on Pretest and Post-test

The score classification of students on Pre-test is described on the table below:

Table 2. Studens' Score Classification on Pretest and Post-test

\begin{tabular}{lccccccccc}
\hline & $\begin{array}{c}\text { Range } \\
\text { Score }\end{array}$ & \multicolumn{2}{c}{$\begin{array}{c}\text { Experimental } \\
\text { Group }\end{array}$} & \multicolumn{2}{c}{$\begin{array}{c}\text { Control } \\
\text { Group }\end{array}$} & \multicolumn{2}{c}{$\begin{array}{c}\text { Experimental } \\
\text { Group }\end{array}$} & \multicolumn{2}{c}{$\begin{array}{c}\text { Control } \\
\text { Group }\end{array}$} \\
\cline { 3 - 10 } & & F & $\%$ & F & $\%$ & F & $\%$ & F & $\%$ \\
\hline Excellent & $9.6-10$ & - & - & - & - & 8 & 40 & 1 & 5 \\
Very Good & $8.6-9.5$ & 1 & 5 & 4 & 20 & 7 & 35 & 10 & 50 \\
Good & $7.6-8.5$ & - & - & 2 & 10 & 4 & 20 & 5 & 25 \\
Fairly Good & $6.6-7.5$ & 2 & 10 & 5 & 25 & - & - & - & - \\
Fair & $5.6-6.5$ & 7 & 35 & 2 & 20 & - & - & 1 & 5 \\
Poor & $3.5-5.5$ & 9 & 45 & 6 & 30 & 1 & 5 & 3 & 15 \\
Very Poor & $0-3.5$ & 1 & 5 & 1 & 5 & - & - & - & - \\
\hline & Total & 20 & 100 & 20 & 100 & 20 & 100 & 20 & 100 \\
\hline
\end{tabular}

Table 2 shows the frequency and the percentage of students of Experiemental group and control group of their achievement after having pre-test and post-test. Based of the table above, the result of students of Experimental Group on pre-test shows there are 1 (5\%) student get score which is classified as Very Good, 2 (10\%) students get score which is classifed as Fairly Good, 7 (35\%) students get score which is classifed as Fair, 9 (45\%) students get score which is classified as Poor and $1(5 \%)$ student get score which is classified as Very Poor and none of them get score which are classified as Excellent and Good. Meanwhile, the result of students of Control Group on pre-test shows there are 4 (20\%) students get score which is classified as Very Good, 2 (10\%) students get score which is classifed as Good, 5 (25\%) students get score which is classifed as Fairly Good, 2 (10\%) students get score which is classified as Fair , 6 (30\%) students get score which is classified as Poor and 1 (5\%) student get score which is classified as Very Poor and none of them get score which is classified as Excellent. Furthermore, on post-test, the students of experimental group shows that there are $8(40 \%)$ students get score which is classified as Excellent, 7 (35\%) students get score which is classified as Very Good, 4 (20\%) students get score which is classified as Good, and only 1 (5\%) student get score which is classified as Poor. While, the result of students on Control Group on post-test shows that there are $1(5 \%)$ student gets score which is classified as Excellent, 10 (50\%) students get score which is classified as Very Good, 
$5(25 \%)$ students get score which is classified as Good, 1 (5\%) student get score which is classified as Fair and still $3(15 \%)$ students get score which is classified as Poor. However none of students from both groups get score which are classified as Fairly Good and Very Poor.

Statistic Description of Students' Score on Pre-test and Post-test

The statistic despription of students' score of both Experimental Group and Control Group on Pre-test and Post-testis presented in the following table:

Table 3. Statistic Desccription of Students' Score on Pre-test and Post-test

\begin{tabular}{lcccc}
\hline Statistic & $\begin{array}{c}\text { Pre-testExperi } \\
\text { mental Group }\end{array}$ & $\begin{array}{c}\text { Post-testExper } \\
\text { imental Group }\end{array}$ & $\begin{array}{c}\text { Pre-test } \\
\text { Control } \\
\text { Group }\end{array}$ & $\begin{array}{c}\text { Post-test } \\
\text { Control } \\
\text { Group }\end{array}$ \\
\hline $\mathrm{N}$ & 20 & 20 & 20 & 20 \\
Minimum & 3,0 & 4,6 & 2,4 & 3,8 \\
Maximum & 9,0 & 10,0 & 9,2 & 9,8 \\
Sum & 108,4 & 177,8 & 127,2 & 158,2 \\
Mean & 5,420 & 8,890 & 6,360 & 7,910 \\
Std. Deviation & 1,3579 & 1,2456 & 1,9613 & 1,6939 \\
Range & 6,0 & 5,4 & 6,8 & 6,0 \\
\hline
\end{tabular}

Table 3 shows that from 20 number of students of Experimental group the mean score is 5,420 on pre-test and increased significantly on post-test to 8,890 while students of Control group the mean score of students is 6,360 on pre-test and slightly increased to 7,910. The standard deviation of students of Experimental Group score on pre-test is 1,3579 and on post-test is 1,2456. The standard deviation of students of control group on pre-test is 1,9613 and on post-test is 1,6939. In addition, the range score of students of Experimental Group on Pre-test is 6,0 and on Post-test is 5,4 while the range score of students of Control Group on Pre-test is 6,8 and on Post-test is 6,0. The table shows the standard deviation and the range score of both groups are decreased in small number. It means that both groups show a little difference from the results achieved. However, the mean score shows significant result for students of Experimental Group. It means it shows enhancement more than control group.

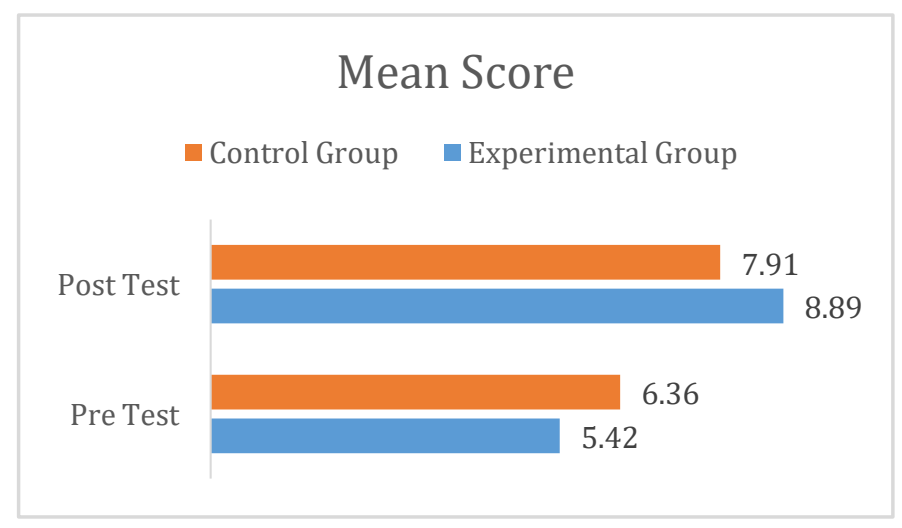


Figure 1. The comparison of students' mean score on pre-test and post-test

Figure 1 shows students of experimental group show the significant improvementof mean score from 5,42 on pre-testwhich is classified as Poor to 8,89 on post testwhich is classified as Very Good after given treatment using Spot It! Card Game. While students of control group also show improvementof mean score but not significant as from 6,36 on pre-testwhich is classified as Fair to 7,91 on post-testwhich is classified as Good after given treatment using conventional method.

\section{Discussion}

By seeing the data above, it could be concluded that students of Experimental Group show significant enhancementof achivement after given treatment using Spot It! Card game in learning vocabulary. This result provides reinforcement of previous study conducted by Kurniah (2018) who investigated the effectiveness of Find A Match game card in increasing students' vocabulary mastery. After playing Find A Match Game Card, the students showed improvement from the low score on pre-test to the high score on post-test.The average score of students on the pretest was 5.2 which was classified as Poor result and the average score of students on the posttest was 9.4 which was classified as Very Good result. It indicated the same result with this study even though the method used was different. The previous study used pre-experimental research design and this study used quasi-experimental research design. However, by seeing the result of both studies, it can be concluded that Spot It! Card Game is effective in enhancing students' vocabulary mastery.

Students' response in questionnaire showed their appreciation on the treatment using Spot It! Card game in learning vocabulary during distance learning. All students agreed that the treatment was effective in storing new vocabulary because of the cards provided images that were easy to remember and the game played was fun. This was in line with Razali (2017) findings that the "Got It" card game made students better at remembering words and enjoying lessons while playing.

Furthermore, students of Experimental Group agreed that learning vocabulary while playing the card game was much better than just memorizing vocabulary and it made the class be less stressful during distance learning. It was also proven by their enthusiasm in quiz. They could match the images, mentioned the images' name well and also spell them correctly. Moreover,the students agreed Spot It! Card game could be played not only in the classroom or distance learning but also would be fun to play at home with family while learning vocabulary.

In addition, learning vocabulary using games, students could gain positive attitude as investigated by Tanasy (2019) after conducted the classroom action research to first grade students of English Education in Universitas Muslim Maros on academic year 2018/2019 in improving students' vocabulary mastery through 
word connection game. This research is in line with Kuzu and Ural (as quoted in Donmus, 2010) believe that:

"when games and education are combined, it can be educative and education environments can be entertaining. The learners who learned with the use of games, gain positive attitudes and can be more motivated while learning "

\section{Conclusion}

Spot It! Card Game is effective in enhancing vocabulary masteryof the second year students of SMA Pesantren Modern Datuk Sulaeman Palopo in distance learning. It was proven by the significant improvement of the mean score from the pre-test which is 5.42 and classified as poor result to 8,89 on the post-test which is classified as very good result. From the conclusion, it can be suggested that Spot It! Card Game is effective as one of strategy in learningvocabulary during distance learning or in the classroom. Moreover it can be played by learners independently or with family at home.

Yet, this study still needs to be reinvestigated in the actual classroom after the pandemic situation for further research to see whether it has the same or different result. Nevertheless, the study of enhancing students' vocabulary mastery using Spot It! Card Game in distance learning such a novelty that can be used as reference for further research related to vocabulary teaching strategies in distance learning due to there have been many English online classes opened to public. Furthermore, this study is also useful as a reference for the development of English vocabulary teaching media.

\section{Acknowledgement}

This study was supported by the Research Fund provided by Ministry of Research and Technology/National Research and Innovation Agency (Hibah PDP Kementerian Riset dan Teknologi Republik Indonesia). Many thanks also to all participants of this study, the second years tudents of SMA PMDS Palopo, the English teacher and the Headmaster.

\section{References}

Agung, G. (2017). Short Stories: The Powerful Media to Foster Students Vocabulary Mastery in Reading. IDEAS: Journal on English Language Teaching and Learning, Linguistics and Literature, 5(1). doi:https://doi.org/10.24256/ideas.v5i1.155

Derakhshan, A., \& Davoodi Khatir, E. (2015). The Effects of Using Games on English Vocabulary Learning. Journal of Applied Linguistics and Language Research.

Donmus, V. (2010). The use of social networks in educational computer-game based foreign language learning. Procedia - Social and Behavioral Sciences. https://doi.org/10.1016/j.sbspro.2010.12.355

Guzacheva, N. (2020). Zoom Technology as an Effective Tool for Distance Learning in Teaching English to Medical Students. Bulletin of Science and Practice. https://doi.org/10.33619/2414-2948/54/61 
Huyen, N. T., \& Nga, K. T. (2003). Learning Vocabulary through Games: The Effectiveness of Learning Vocabulary Through Games. Asian EFL Journal.

İnal, H., \&Cakir, A. (2014). Story-based Vocabulary Teaching. Procedia - Social and Behavioral Sciences. https://doi.org/10.1016/j.sbspro.2014.03.467

Ilinawati, I., \& Dharma, Y. P. (2019). Improving Students' Vocabulary Through Songs. JEES: Journal of English Educational Study. https://doi.org/10.31932/jees.v1i2.329

Komachali, M. E., \& Khodareza, M. (2012). The effect of using vocabulary flash card on Iranian pre-university students' vocabulary knowledge. International Education Studies. https://doi.org/10.5539/ies.v5n3p134

Kurniah. S.A., Rusliana (2018) The Effectiveness of Find A Match Game Card in Increasing Students' Vocabulary.International Journal of Science \& Development Research.

Lestari, I., \& Isma, A. (2019). Using Translation Activity to Improve the Students' Vocabulary Mastery of the Eleventh Grade of Social Class at SMAN 3 Bojonegoro. IDEAS: Journal on English Language Teaching and Learning, $\begin{array}{lll}\text { Linguistics } \quad \text { and } & \text { Literature, }\end{array}$ doi:https://doi.org/10.24256/ideas.v7i2.1034

Munawir, A. (2019). Online Game and Childrens's Language Behavior. IDEAS: Journal on English Language Teaching and Learning, Linguistics and Literature, 7(2). doi:https://doi.org/10.24256/ideas.v7i2.1050

Razali, W. N., Amin, N. M., Kudus, N. V., Musa, M. K., Teknologi, U., Cawangan, M., \& Pinang, P. (2017). Using Card Game to Improve Vocabulary Retention: A Preliminary Study Article Information. International Academic Research Journal of Social Science.

Reski, P. (2016). The Ability of the First Years Students In Mastering Vocabulary at SMP Negeri 10 Palopo. IDEAS: Journal on English Language Teaching and Learning, Linguistics and Literature, 4(1). doi:https://doi.org/10.24256/ideas.v4i1.178

Shanty, H. (2017). Students Vocabulary and Pairs Teaching. IDEAS: Journal on English Language Teaching and Learning, Linguistics and Literature, 5(1). doi:https://doi.org/10.24256/ideas.v5i1.161

Taka, S. D. (2019). The Effectiveness of Pairs Teaching In Teaching Vocabulary at SMA Kristen MercusuarKupang. IDEAS: Journal on English Language Teaching and Learning, Linguistics and Literature. https://doi.org/10.24256/ideas.v7i1.728

Tanasy, N. (2019). Improving The Vocabulary Mastery Through Word-Connection Game. ETERNAL (English, Teaching, Learning, and Research Journal). https://doi.org/10.24252/eternal.v52.2019.a12

Wahibah, W. (2016). The Effectiveness of Using Pictured Story to Upgrade Students Vocabulary. IDEAS: Journal on English Language Teaching and Learning, Linguistics and Literature, 4(1). doi:https://doi.org/10.24256/ideas.v4i1.179 